\title{
MAKING EAST ASIAN REGIONALISM WORKS ${ }^{1}$
}

\author{
Fithra Faisal Hastiadi ${ }^{2}$
}

\begin{abstract}
For the past few years, regionalism has been progressing in East Asia with the likes of China, Japan, and Korea (CJK) as the most prominent actors. Unfortunately, with the absence of trade arrangement amongst the CJK, the present regional trade scheme is not sufficient to reach sustainability. This paper uncovers the inefficient scheme through Engle-Granger Cointegration and Error Correction Mechanism. Moreover, the paper underlines the importance of triangular trade agreement for accelerating the phase of growth in CJK which eventually create a spillover effect to East Asia as a whole. Employing Two Stage Least Squares in a static panel fixed effect model, the paper argues that the spillover effect will function as an impetus for creating region-wide FTA. Furthermore, the paper also identifies a number of economic and political factors that can support the formation of East Asian Regionalism.
\end{abstract}

JEL Classification: F15, C13, C22, C33

Keywords: Regionalism, Engle-Granger Cointegration, Error Correction Mechanism, Fixed Effect, Two Stage Least Squares

1 Earlier version of this paper has been presented on the International Conference on Business and Economics held in Bukit Tinggi, Indonesia (April 2010) and Thessaloniki, Greece (May 2010)

2 Graduate School of Asia-Pacific Studies (GSAPS), Waseda University 1-21-1 Nishi-Waseda, Shinjuku-ku, Tokyo 169-0051, JAPAN E-mail: fithra@asagi.waseda.jp 


\section{INTRODUCTION}

In this new millennium, regionalism has begun to emerge in East Asia. East Asian Countries have been focusing on ways to expand intra regional trade that include: the establishment of Regional Trade Agreements (RTAs) in the form of Free Trade Agreements (FTAs) and Economic Partnership Agreements (EPAs). The trend towards regionalism has created a profound regional and indeed global significance (Harvey and Lee, 2002). Japan, Korea and China are regarded as the key actors for such action in East Asia.

Being acknowledged as the economic front runners, Japan, China and Korea are assumed to have heavy responsibility for the economic welfare in the East Asian region. It is very obvious that East Asian regionalism cannot be put into practice without these countries' strong support. Unfortunately, the lack of institutional arrangements among these giant countries has stalled the overall welfare effect for the East Asian communities. The present driving force of the China-Japan-Korea (CJK) relationship is the market by which in some sense is not enough; it should be matched by regionalism. The main focus of the regionalism is to make these countries grow together so that it can spread positive externalities throughout the East Asian region. In the long run it is expected that CJK will lead regionalism in East Asia.

The remainder of the paper is organized as follows. The second section studies the economic structures and trade patterns in the CJK. The third section examines the effect of openness in the CJK to economic growth in these particular countries. The fourth section analyzes the prospects of the CJK increased welfare in creating spillover effect to ASEAN4, which in this paper serves as a proxy for ASEAN countries. The fifth section presents the future trend and path towards East Asian Regionalism, and finally the last section presents some concluding remarks.

\section{REVIEW ON JAPAN, CHINA AND KOREA ECONOMIC RELATION}

Tracing back the relations since the post war era, economic ties between Japan, Korea and China has evolved in somewhat gradual ways. The evolution of trade activities emerged from the likes of China, which has a substantial transformation of trade structures. In the early 90's, primary commodities accounted for more than one third of China's total export to Japan and Korea. In this new millennium, it is still top Chinese export to Japan and Korea, but it is persistently followed by the fast growth of machinery and transport (Chan and Chin Kuo, 2005). From this point of view, trade within the north East Asian region is deemed to have substantial movement as a result from the shift of trade towards a more industrialized structure. The emergence of China as a regional manufacturing center is a dominant factor that contributes the trade shift. 
The overall picture of the trade amongst these countries is described in Diagram V.1. It is clear that trade activity is very intense by which performs as the major contributing factor for economic growth in the region. The vast amount of trade has been very likely steered up by the amount of FDI flows among them with Japan as the sole leader of it (Diagram V.2). In other words, the creation of economic transformation in China and Korea that geared up the trade was enchanted by Japan's role in making investment in those countries.

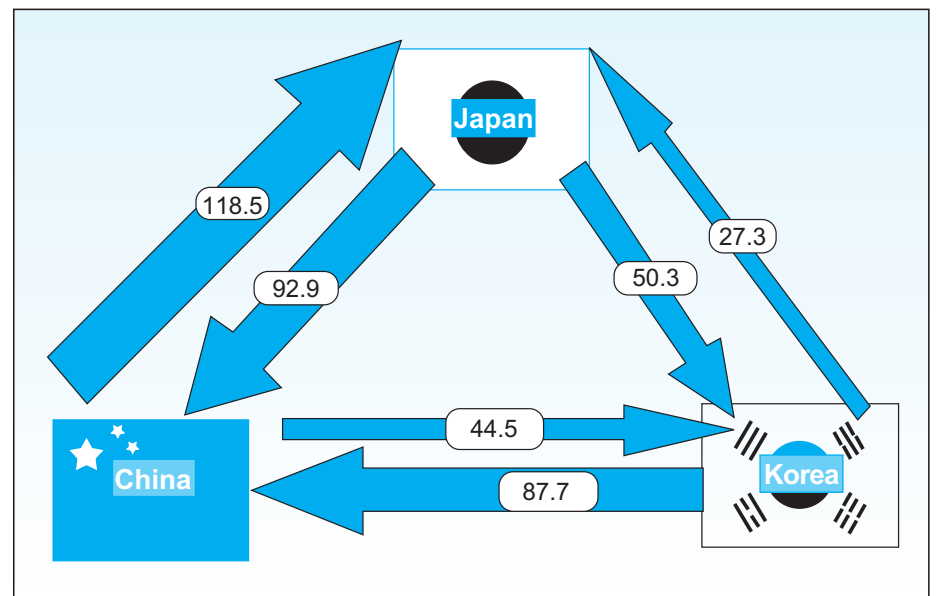

Source: Watanabe (2008)

Diagram V.1.

Trade among Japan, China and Korea (2006, \$Billion)

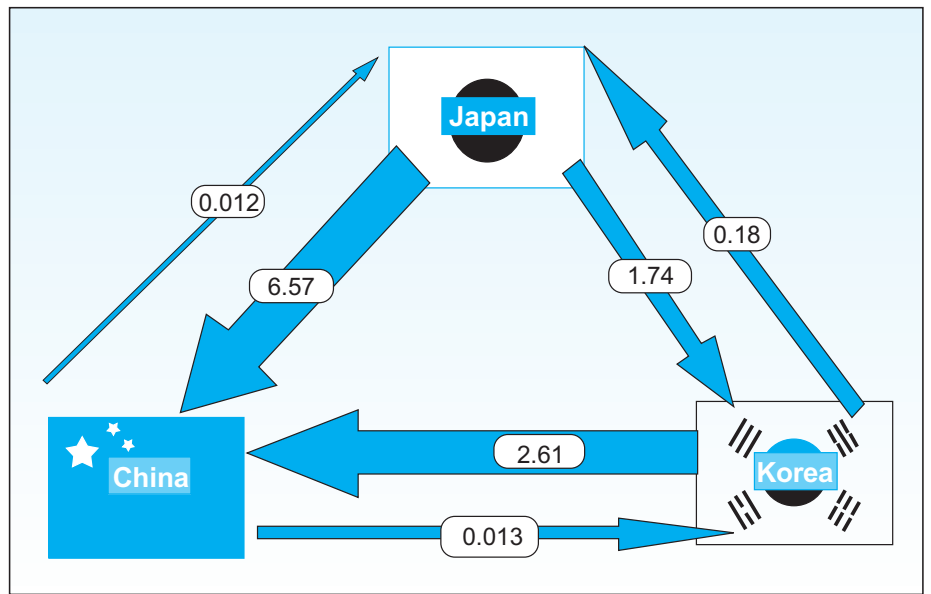

Source: Watanabe (2008)

Diagram V.2.

Investment among Japan, China and Korea (2005, \$Billion) 
To some extent, trade is almost synonymous to a country's welfare. More specifically, some research pointed out export as an engine of economic growth. From this stand point, it is important to measure export sustainability to the economy, which in this section export among the CJK become the main focus.

As already explained earlier, Japan, China and Korea are experiencing golden period in doing export among them. Economic welfare is the most notable goal which links in this activity, but is it sufficient to boost the economy in the long run? A pure market driven activity without specific regional trade agreement might sometime create bias. It is clear that Japan, Korea and China are lacking of such agreement among them (Urata and Kiyota, 2003) as described in the table V.1.

\begin{tabular}{l|l|l}
\multicolumn{1}{c}{ Japan, China and Korea FTAs/EPAs } \\
\multicolumn{1}{c|}{ Countries } & \multicolumn{1}{c}{ Situation } & \multicolumn{1}{c}{ Countries } \\
& Concluded & Chile, ASEAN, Hong Kong, Macao \\
\hline China & Under Negotiations & NZ, Australia, Pakistan, Singapore, GCC, SACU \\
\hline & Under Considerations & Iceland, India, Japan-Korea-China, FTAAP, Switzerland \\
\hline Korea & Concluded & Chile, Singapore, EFTA, ASEAN, USA \\
\hline & Under Negotiations & India, Mexico, Canada, EU \\
\hline & Under Considerations & $\begin{array}{l}\text { FTAAP, China, Mercosur, NZ, South Africa, Japan-China-Korea, } \\
\text { Australia, GCC }\end{array}$ \\
\hline & Concluded & $\begin{array}{l}\text { Singapore, Mexico, Malaysia, Philippines, Chile, Thailand, } \\
\text { Brunei, Indonesia }\end{array}$ \\
\hline Japan & Under Negotiations & India, Vietnam, Australia, Switzerland, Korea, GCC, ASEAN \\
\hline & Under Considerations & FTAAP, Japan-China-Korea, South Africa
\end{tabular}

Source: Japanese Ministry of Economy, Trade and Industry, 2007

To make an effective regionalism, Japan, China and Korea should support each other. Therefore, intra regional cooperation within the CJK must take place by which can create sustainable growth in East Asian region. The following sections serve to prove export sustainability to economic growth, in the absence of trade arrangements, for the short and the long run. Engle-Granger Cointegration and Error Correction Mechanism test are then employed for this cause. This test employs time series quarterly data of GDP and for Japan, China and Korea ranging from 1985 to 2004. The data is taken from CEIC database.

In doing Engle Granger Cointegration test, this paper divides the export relationship in to three parts which are described in the following equations: 
i. China and Japan Export Relationship

$$
\begin{array}{ll}
J P G D P & =\beta_{o}+\beta_{1} \cdot \text { ExportCH }+\mu_{t} \\
C H G D P & =\beta_{o}+\beta_{1} \cdot \operatorname{ExportJP}+\mu_{t}
\end{array}
$$

ii. Korea and Japan Export Relationship

$$
\begin{array}{ll}
\text { KRGDP } & =\beta_{o}+\beta_{1} \cdot \text { ExportJP }+\mu_{t} \\
J P G D P & =\beta_{o}+\beta_{1} \cdot \operatorname{ExportKR}+\mu_{t}
\end{array}
$$

iii. China and Korea Export Relationship

$$
\begin{array}{ll}
C H G D P & =\beta_{o}+\beta_{1} \cdot \operatorname{ExportKR}+\mu_{t} \\
K R G D P & =\beta_{o}+\beta_{1} \cdot \operatorname{ExportCH}+\mu_{t}
\end{array}
$$

In these equations, JPGDP, CHGDP and KRGDP are Japan's GDP, China's GDP, and Korea's GDP respectively while Export JP, Export $\mathrm{CH}$ and Export $\mathrm{KR}$ are the variables of export destinations to Japan, China and Korea. It would be possible to cointegrate Export and GDP since the trend

\begin{tabular}{|c|c|c|c|}
\hline \multicolumn{4}{|c|}{$\begin{array}{c}\text { Table V.2 } \\
\text { Cointegration Parameters }\end{array}$} \\
\hline Dependent Variable & GDP (Japan) & GDB (China) & GDB (Korea) \\
\hline \multicolumn{4}{|l|}{ Independent Variable } \\
\hline Export to Jepang & na & Stationer & Stationer \\
\hline Export to China & Stationer & na & Stationer \\
\hline Export to Korea & Stationer & Stationer & na \\
\hline
\end{tabular}
in export and GDP would offset to each other, creating a stationary residual. The residual is called a cointegration parameter. In the data, if we find that the initial regression of the residual (ut) gives stationarity it means that $u$ t is stationary at order 0 (level) and it is notated as I(0). But if $u t$ is stationer in first difference, the variables of Export and GDP will be cointegrated in the first difference which can be notated with I(1).

From table V.2 we can see that, GDP and export relationship in the CJK yields stability in the long run. It is proven by the stationarity of the error term in each of the cases. The cointegration test that proves long run equilibrium describes that the model is not spurious. 
Export is proven to be the engine of economic advancement in these countries. It approves some previous research as the likes of Dorasami (1996), and Ekanayake (1999) of export and economic growth relationship.

We have seen the long run relationship between Export and GDP. However, in order to make it objective, we should also see the short run since it is still plausible to perceive disequilibrium. Thus, could be noted as equilibrium error. This error then could be used to relate the behavior of the short run Japanese GDP The technique to correct short-run disequilibrium to its long run long run equilibrium is called Error Correction Mechanism (ECM). The model of ECM is as follows:

$$
\Delta G D P_{-} X \quad=\beta_{o}+\beta_{1} \cdot \Delta E x p o r t_{-} Y+\beta_{2} \cdot \mu_{t-1}+e_{t}
$$

$\mu_{t-1}$ is a cointegrated error lag 1 , or could be noted mathematically as:

$$
U_{t-1}=\text { GDPCountry } X_{t-1}-\beta_{o}-\beta_{1} \text { ExportCountry } Y_{t-1}
$$

In this equation, $\triangle G D P C$ country $X$ is the difference in GDP for Japan, Korea and China, while $\Delta$ ExportCountry $Y$ is the difference in export from country $X$ to Country $Y$. As for example, applies for the effect of Japan's export to China on Japan's GDP. From the above model we can see that the long run relation between Export and GDP in Japan, China and

\begin{tabular}{|c|c|c|c|}
\hline & $\begin{array}{l}\text { V.3 } \\
n \text { Errors }\end{array}$ & & \\
\hline Dependent Variable & \multirow{2}{*}{ GDP (Japan) } & \multirow{2}{*}{ GDP (China) } & \multirow{2}{*}{ GDP (Korea) } \\
\hline Independent Variable & & & \\
\hline Equilibrium error for Export to Japan & na & $-1.09 * * *$ & $-0.23 *$ \\
\hline Equilibrium error for Export to China & $-0.18 * * *$ & na & $-0.48 * * *$ \\
\hline Equilibrium error for Export to Korea & 0.017773 & $-1.33 * * *$ & na \\
\hline
\end{tabular}
Korea would be balanced by the previous error. Below is the output for each country's regressions:

Note: Statistical significance is indicated by *(10\%), **(5\%), and ***(1\%)

\section{i. Japan}

In the short run, there is an equilibrium error for Japan's Export to China with its relation to Japan's GDP. The coefficient of residual gives negative sign (-0.18), which means that Japan's Export to China is below the long run equilibrium. This will only lead to a rise of export for the 
following periods. But it is important to note that the absolute value of the coefficient (adjustment rate) is very small (0.18). This suggests that Japan's Export to China is moving in a slow phase to reach the long run equilibrium.

As for the relationship between Japan and Korea, the equilibrium error of the export trend is not significant. These suggest that Japan's GDP is adjusting to the change in Japan's export to Korea in the same period of time. In other words, Japan and Korea relationship in terms of export has already reached steady state level.

\section{ii. China}

The residuals for the relationship between China's GDP with China's Export to Japan and Korea are significant. These suggest that there is an equilibrium error in the short run. The negative signs put the Export for a constant rise to reach the long run equilibrium. In China's case, the adjustment rate or the phase of acceleration for the long run equilibrium is very fast. It can be seen through the absolute value of the equilibrium error coefficients which are 1.09 and 1.33 for China's relationship to Korea and Japan respectively.

\section{iii. Korea}

Korea's case is somewhat similar to China. The residuals for the relationship between Korea's GDP with Korea's Export to Japan and China are significant. It yields similar explanation with China's case. However, the adjustment rate for the case of Korea is slower than China's but it is still faster than Japan's. It gives the absolute value of 0.23 and 0.48 for Korea's trade relationship to Japan and China respectively.

From the ECM, we can conclude that North East Asian region is not moving at the same phase to reach the long run equilibrium, which in this case Japan is the slowest one. The insignificant value of acceleration rate for the case of Japan trade relationship with Korea is also important point to note since it can be interpreted as an exhausted Korean market for Japanese products (steady state condition). These facts are very crucial since it diminishes Japan's role as the sole leader in the north East Asia. Although whoever the leader is not to important, but the stalled effect of a country's economic growth in these region will only serve as stumbling blocks in creating East Asian welfare. The rising growth of China and Korea will soon meet its end mimicking the pattern of Japan if no serious action is site4. Therefore, In order to strengthen regional welfare and accelerate the phase of adjusting, economic integration must take place. 


\section{THE OPENNESS IN TRADE}

Greater economic interdependence between Japan, China and Korea will act well as the base of creating regionalism. In this sense, triangular trade agreements that dismantle trade barriers will smooth the progress of improved trade flows among these countries by means of greater market access. But unfortunately, this supporting environment only operates as fact in a sheet. The process of regionalism in this area is proven to be difficult.

These countries may have aggressively reached other countries in making FTA's and EPA's but none of which have been progressing among them (see table V.1). The reason of it will be a subject for another research, while this section tries to focus on the effect of such agreement to the economy. The lack of trade arrangements is being noted as the main factor that contributes intra regional trade ineffectiveness in north East Asia. This hypothesis will be proved in the following sections to come.

Export lead growth approach that has been done in the previous section with cointegration and error correction model has actually provided the basis to measure openness of a country, but in some ways this alone is not enough. It only works for confirming the paradigm of trade as an engine of growth but it is not sufficient to measure a more robust pattern of openness. Therefore, we then may have to address Dollar's Relative Price Level (RPL index).

This index is a measure of outward orientation of an economy which was explored by Summers and Heston (1988). Using the US as the benchmark country, the index of country i's relative price level $(\mathrm{RPL})$ is:

$$
R P L_{i} \quad=100 \times P_{i} / P_{u s} \times 1 / e
$$

Where $e$ is the exchange rate and $P_{i}$ is the consumption price index for country $i$ and $P_{u s}$ is the consumption price index for US. Therefore, we can use the formula to measure inward- or outward-orientation of a trade policy. With using the same analogy, this paper then customizes the RPL index into this formula:

$$
R P L_{i} \quad=100 \times P_{i} / P_{t p} \times 1 / e
$$

Where $P_{t p}$ is the consumption price index for the trading partner and e is the exchange rate (no. of units of domestic currency per unit of trading partner currency). The customized RPL is then become a powerful tool to analyze trade openness between the trading countries. 
As already explained in the previous section, ECM provides the description of short run shock. In this particular case, we examine the openness vis a vis trade liberalization trend in north East Asia region. This test employs time series quarterly data of Exchange rate, CPI, Export for CJK ranging from 2001 to 2005, the data is taken from CEIC data base. Below is the equation:

$$
\Delta G D P \_X \quad=\beta_{o}+\beta_{1} . \Delta R P L \_Y+\beta_{2} \cdot \mu_{t-1}+e_{t}
$$

This equation mimics equation V.7, but the previous dependent variable is substituted from export to RPL in order to suit the goal which is to measure the openness. $\triangle G D P$ Country $X$ is the difference in GDP from Japan, Korea and China, $\triangle R P L$ Country $Y$ is the difference in $R P L$ from a country $X$ to Country $Y$. $\triangle R P L$ Country $Y$ measures the openness of trade from of country $X$ towards $Y$. Below is the outputs for each country:

\begin{tabular}{|c|c|c|c|}
\hline Coir & $\begin{array}{l}\text { V.4 } \\
\text { Parameters }\end{array}$ & & \\
\hline Dependent Variable & \multirow{2}{*}{ GDP (Japan) } & \multirow{2}{*}{ GDP (China) } & \multirow{2}{*}{ GDP (Korea) } \\
\hline Independent Variable & & & \\
\hline Equilibrium error for Openness to Japan & na & $-1.23 * * *$ & $-1.31 * \star \star$ \\
\hline Equilibrium error for Openness to China & $-1.15 * * *$ & na & $-0.97 * * *$ \\
\hline Equilibrium error for Openness to Korea & $-0.72 * *$ & $-1.24 * * *$ & na \\
\hline
\end{tabular}

Note: Statistical significance is indicated by $*(10 \%), * *(5 \%)$, and ***(1\%)

From this particular test we can see that generally trade openness is affecting a country's GDP in a positive way. But in the short run, trade openness in the CJK is still below the equilibrium. This suggests that trade openness is still finding its form in this area. Although we might not see regionalism which liberalize trade in the short run, but the trend towards openness in trade vis a vis regionalism is progressing in a respectful manner. We can see this through the adjustment rate for the long run equilibrium (the coefficients of residuals) that yields an average of 1.1, consequently we might see regionalism in North East Asia happen in the future.

\section{THE SPILLOVER EFFECT FROM JAPAN-KOREA-CHINA TRIANGULAR TRADE TO ASEAN 4}

As giants of Asia, the growth of Japan, Korea and China will most likely create positive effect to the neighboring countries. Regionally speaking, the growth of North East Asia will 
boost the East Asian growth as whole, in this sense we might want to exercise its effect to ASEAN countries. To simplify things, this paper limits the effect to ASEAN4 since these countries have the same economic characteristics. This paper employs static panel data model for this purpose. The panel data is analyzed annually from 1989 to 2007 which consist of ASEAN 4's Export, Import, Consumption, Investment, Government expenditure, GDP, and GDP of Japan, China, Korea. The data is taken from WDI online database. The following sections provide the analysis.

A static panel data model can be specified as follows:

$$
Y_{i t}=X_{i t} \beta+\lambda_{t}+\eta_{i}+\varepsilon_{i t}, \quad t=1, \ldots, T i=1, \ldots, N
$$

Where: $\lambda_{t}$ and $\eta_{t}$ are time and individual specific effects respectively, $x$ it is a vector of the explanatory variables, (i) is the time component of the panel, $(N)$ is the cross-section dimension (or the number of cross-section observations), and $N \times T$ is the total number of observations. The idea is to run the models in order to have a consistent estimator for the $\beta$ coefficients, and the model (fixed or random) choice depends on the hypothesis assumed for the relationship between the error-term ( $\varepsilon$ it) and the regressors ( $x$ it). The static panel data analysis developed in the empirical section of the paper was based on two basic panel models, the fixed (FE) and the random (RE) effect models. Since the time periods (19892007) exceed the individual observations (Indonesia, Malaysia, Thailand, Philippines) therefore FE is considered as the most appropriate method (Nachrowi and Usman, 2008). The model is described as follows:

$$
Y_{i t}=\alpha+\beta_{1} \cdot X_{i t}+\gamma_{1} W_{1 t}++\gamma_{2} W_{2 t}+\ldots++\gamma_{N} W_{N t}+\delta_{1} Z_{i 1}+\delta_{2} Z_{i 2}+\ldots+\delta_{T} Z_{i T}+e_{i t}
$$

Where:

$\mathrm{Y}_{\mathrm{it}} \quad=$ GDP growth of ASEAN 4 for time $\mathrm{t}$ and country $\mathrm{i}$

$\mathrm{X}_{\mathrm{it}} \quad=$ Independent Variables (ASEAN 4 consumption growth, investment growth, government expenditure growth, export-import growth and Japan-China-Korea GDP growth for time $\mathrm{t}$ )

$\mathrm{W}_{\mathrm{it}}$ and $\mathrm{Z}_{\mathrm{it}}$ are dummy variables which are defined as follows:

$\mathrm{W}_{\text {it }}=1$ for country $\mathrm{i}$, where $\mathrm{i}=$ Indonesia, Malaysia, Philippines, Thailand $=0$ for others 
$\mathrm{Z}_{i t}=1$ for Period $\mathrm{t}$ where $\mathrm{t}=1989,1990 \ldots, 2007$

$=0$ for others

The above structural equation is actually a simultaneous equation in which employs causality relationship. To see the simultaneity, the above model can be decomposed into four parts:

$Y_{t}=\beta_{1}+\beta_{2} \cdot C_{t}+\beta_{3} \cdot I_{t}+\beta_{4} \cdot G_{t}+\beta_{5} \cdot X_{t}+\beta_{6} \cdot J G D P_{t}+\beta_{7} \cdot C G D P_{t}+\beta_{8} \cdot K G D P_{t}$

$C_{t}=\beta_{1}+\beta_{2} \cdot C_{t-1}+\beta_{3} \cdot Y_{t}$

$I_{t}=\beta_{1}+\beta_{2} \cdot r_{t}+\beta_{3} \cdot Y_{t}$

$X_{t}=\beta_{1}+\beta_{2} \cdot E X_{t}+\beta_{3} \cdot C_{t}+\beta_{4} \cdot J G D P_{t}+\beta_{5} \cdot C G D P_{t}+\beta_{6} \cdot K G D P_{t}$

Equation V.14 describes the effects of ASEAN 4 consumption $\left(C_{t}\right)$, investment $\left(I_{t}\right)$, government expenditure $\left(G_{t}\right)$, export growth $\left(X_{t}\right)$ and the North East Asian GDP growth (JGDP, $\left.C G D P_{t}, K G D P_{t}\right)$ on ASEAN4 GDP growth $\left(Y_{t}\right)$. From the model, it is clear that consumption growth, investment growth and export growth have their own determinants that simultaneously form the structural equation. Consumption growth $\left(C_{t}\right)$ is formed by last year's consumption growth $\left(C_{t-1}\right)$, and the present GDP growth $\left(Y_{t}\right)$, Investment $\left(I_{t}\right)$ on the other hand is influenced by the interest rate $\left(r_{t}\right)$ and the GDP growth $\left(C_{t}\right)$. It is also expected that exchange rate $\left(E X_{t}\right)$, consumption growth $\left(C_{t}\right)$ and trading partners economic growth $\left(J G D P_{t}, C G D P_{t}, K G D P_{t}\right)$ have some influences on export growth $\left(X_{t}\right)$ for ASEAN 4.

From the structural equation, we can divide the variables into two, endogenous and predetermined (exogenous). The first one is treated as stochastic while the latter as non stochasti3. To see which simultaneous model that can satisfies the need, we have to address the identification process. If $\mathrm{K}$ is the number of exogenous variables within the model, $\mathrm{k}$ is the number of exogenous variables within the equation and $\mathbf{M}$ is the number of endogenous variable within the model, so the criteria to state whether an equation is unidentified, just identified, or over identified are describe as follows:

If $\mathrm{K}-\mathrm{k}<\mathrm{M}-1$, so the equation is unidentified

If $\mathrm{K}-\mathrm{k}=\mathrm{M}-1$, so the equation is exactly identified

If $\mathrm{K}-\mathrm{k}>\mathrm{M}-1$, so the equation is over identified

Based form the above criteria, table V.5 summarize the order condition from the system: 


\begin{tabular}{c|c|c|c}
\multicolumn{5}{c}{$\begin{array}{c}\text { Table V.5 } \\
\text { Order Condition }\end{array}$} \\
No & Equation & Criteria & Conclusion \\
1 & $Y_{t}$ & $6>2$ & over identified \\
\hline 2 & $C_{t}$ & $9>1$ & over identified \\
\hline 3 & $\mathrm{I}_{t}$ & $9>1$ & over identified \\
\hline 4 & $\mathrm{X}_{t}$ & $6>1$ & over identified \\
\hline
\end{tabular}

For the case of over identified, we might want to employ two stage least squares (2SLS) approach as an elegant way to deal with such problem. 2SLS regression analysis, as suggested by Angrist and Imbens (1995). Below is the detailed procedure of 2SLS.

In stage one, least square regression on the reduced form equation has to take place by which it can yields $\mathrm{C}_{\mathrm{t}-1}, \mathrm{Y}_{\mathrm{t}-1}, \mathrm{r}_{\mathrm{t}}, \mathrm{G}_{\mathrm{t}}, \mathrm{EX}_{\mathrm{t}}, \mathrm{JGDP}_{\mathrm{t}}, \mathrm{CGDP}_{\mathrm{t}}, \mathrm{KGDP}_{\mathrm{t}}$ as the instrumental variables, therefore all equations from $\mathrm{V} .14$ up to $\mathrm{V} .17$ have to be transformed into reduced form equation as the followings:

$$
\begin{aligned}
& Y_{t}=\Pi_{1}+\Pi_{2} C_{t-1}+\Pi_{3} Y_{t-1}+\Pi_{4} r_{t}+\Pi_{5} G_{t}+\Pi_{6} E X_{t}+\Pi_{7} J G D P_{t}+\Pi_{8} C G D P_{t}+\Pi_{9} K G D P_{t} \\
& C_{t}=\Pi_{10}+\Pi_{11} C_{t-1}+\Pi_{12} Y_{t-1}+\Pi_{13} r_{t}+\Pi_{14} G_{t}+\Pi_{15} E X_{t}+\Pi_{16} J G D P_{t}+\Pi_{17} C G D P_{t}+\Pi_{18} K G D P_{t} \\
& I_{t}=\Pi_{19}+\Pi_{20} C_{t-1}+\Pi_{21} Y_{t-1}+\Pi_{22} r_{t}+\Pi_{23} G_{t}+\Pi_{24} E X_{t}+\Pi_{25} J G D P_{t}+\Pi_{26} C G D P_{t}+\Pi_{27} K G D P_{t} \\
& X_{t}=\Pi_{28}+\Pi_{29} C_{t-1}+\Pi_{30} Y_{t-1}+\Pi_{31} r_{t}+\Pi_{32} G_{t}+\Pi_{33} E X_{t}+\Pi_{34} J G D P_{t}+\Pi_{35} C G D P_{t}+\Pi_{36} K G D P_{t}
\end{aligned}
$$

Note: $\Pi$ is $(\beta /(1-\beta))$

From stage one we get as the fitted values with which we can run for the second stage. In stage two, these fitted values are then plugged in to the main equation. The last step is to run least squares on each of the above equations to get 2SLS estimation as described below in Table V.6.

From the output above we can conclude that the North East Asian (Japan, Korea and China) economic growth boost the ASEAN4 economic growth, it confirms the proposition of this paper. Investment flows, in the form of FDI, has also operated as a dominant integrating power in East Asia as whole. Although we cannot find legitimate determinant for FDI in the output, but it is clear that FDI is trade related in nature. With its essentially open and outwardlooking economies, the region is highly dependent on foreign investment for its economic 


\begin{tabular}{|c|c|c|c|c|}
\hline Tw & $\begin{array}{r}\text { Tab } \\
\text { Least Squa }\end{array}$ & egression & & \multirow[b]{3}{*}{$x$} \\
\hline Dependent Variable & \multirow[b]{2}{*}{$\mathbf{Y}$} & \multirow{2}{*}{ C } & \multirow{2}{*}{ I } & \\
\hline Independent Variable & & & & \\
\hline$Y$ & na & $0.776 * * *$ & -0.087 & $\mathrm{Na}$ \\
\hline C & $0.470 * * *$ & na & $\mathrm{Na}$ & $-0.64 * *$ \\
\hline 1 & 0.025 & na & $\mathrm{Na}$ & $\mathrm{Na}$ \\
\hline $\mathrm{X}$ & $0.072 *$ & na & $\mathrm{Na}$ & $\mathrm{Na}$ \\
\hline \multicolumn{5}{|l|}{ Instrumental Variable } \\
\hline Y (Japan) & $0.546 * *$ & na & $\mathrm{Na}$ & $2.949 * * *$ \\
\hline$Y($ China) & $0.311 * *$ & na & $\mathrm{Na}$ & $1.112 * * *$ \\
\hline Y (Korea) & $0.250 * *$ & na & $\mathrm{Na}$ & -3.760 \\
\hline$C(-1)$ & na & 0.01 & $\mathrm{Na}$ & $\mathrm{Na}$ \\
\hline $\mathrm{R}$ & na & na & 0.137 & $\mathrm{Na}$ \\
\hline$Y(-1)$ & na & na & $\mathrm{Na}$ & $\mathrm{Na}$ \\
\hline EX & na & na & $\mathrm{Na}$ & 0 \\
\hline G & $0.122 * *$ & na & $\mathrm{Na}$ & $\mathrm{Na}$ \\
\hline
\end{tabular}

Note: Statistical significance is indicated by *(10\%), **(5\%), and ***(1\%)

growth. But still, the boosting power is not as much as in the spillover effect from the giant countries of Japan, Korea and China. Japan, in terms of GDP growth, has the biggest influence towards ASEAN4 followed by China and Korea at the second and third place. This fact is described by the coefficient parameter that gives the value of $0.546,0.311$ and 0.250 for Japan, China and Korea respectively.

The ranking of influence is presumably caused by the number FDI inflows to ASEAN from these countries as described below in Table V.7. The only bias is on China and Korea, even though the cumulative FDI from Korea to ASEAN4 was bigger than China's, but it does not seem to be reflected on the ranking of influence. As for this, it is assumed that the high economic growth rate of China had been the major contributing factor (Urata, 2008) that

\begin{tabular}{|c|c|c|c|c|c|}
\hline \multicolumn{6}{|c|}{$\begin{array}{l}\text { Table V.7 } \\
\text { FDI flows to ASEAN } 4 \text { (US\$ million) }\end{array}$} \\
\hline Host Country & Indonesia & Thailand & Malaysia & Philippines & $\begin{array}{c}\text { Total Cummulative } \\
1995-2003\end{array}$ \\
\hline \multicolumn{6}{|l|}{ Source Country } \\
\hline Japan & 288.06 & $8,096.02$ & $4,761.11$ & $3,055.68$ & $16,200.87$ \\
\hline Korea & 331.88 & 235.58 & 98.51 & 238.13 & 904.1 \\
\hline China & -36.78 & 50.16 & 120.72 & 4.07 & 138.17 \\
\hline
\end{tabular}


overtook the influence of Korea's cumulative FDI flow to ASEAN4. However, such factor is not enough to surpass ${ }^{3}$ Japan's influence to ASEAN4's economic growth since Japan's FDI contribution to ASEAN4 outweighed China's by more than one hundred folds.

The story goes hand in hand with the flying-geese hypothesis that was developed by Japanese economist, Kaname Akamatsu (1935). This model has been frequently proposed to examine the patterns and characteristics of East Asian economic integration. "The premise of the flying-geese pattern suggests that a group of nations in this region are flying together in layers with Japan at the front layer. The layers signify the different stages of economic development achieved in various countries" (Xing, 2007). In the flying-geese model of regional economic development, Japan as the leading goose leads the second-tier geese (China, Korea) which, in their turn, are followed by the third-tier geese (ASEAN4).

Another important thing to note is the low significant value of exports within ASEAN4 in terms of creating GDP growth. These are intriguing facts since export is considered as the main determinant of GDP growth. It is suspected that the effect of rivalry between ASEAN4 members and China is the main factor which creates insignificant value. This factor is supported by Holst and Weiss (2004) that pointed out China's emergence for creating short and medium term direct and indirect competition between ASEAN and China. They argued that ASEAN and China are experiencing intensified export competition in prominent third markets. This can lead to painful domestic structural adjustments within the ASEAN in the short run. Then again the mind set in viewing the economic opportunity or threat depends on whether China's economy is perceived as complementary or competitive vis-à-vis individual ASEAN economies and on whether the latter economies are able to exploit their complementary opportunities and overcome the competitive threats.

Chia (2006) argued that " the differences in resource and factor endowments, production structures, and productivities lead to a complementary relationship, whereas similarities in these areas lead to a competitive relationship." In the long run, regionalism is expected to accommodate welfare for East Asia. The growing significance of China market for ASEAN will serve as the basis for regionalism. Thus, a unified East Asia could accelerate the momentum of overall trade liberalization and boost regional economic growth.

3 From the ECM simulation as confirmed earlier, we found that China has taken over Japan's role in East Asia. But this is true if we address the long run effect. This section only measures the present condition in the absence of the intertemporal problem. 


\section{THE FUTURE OF EAST ASIAN REGIONALISM (EAR)}

The next task is to shape the future of EAR, but then will the future exist? In part $C$ of this paper, we measure the trend toward openness vis a vis regionalism by using ECM for the RPL index in North East Asia (CJK). Since we include two sub regions, the best way to measure it is by using test of convergence of the term of trade for CJK and ASEAN4. The notion of convergence implies that differences between the series must follow a stationary process (Bernard \& Durlauf, 1996; Oxley \& Greasley, 1995). Thus, stochastic convergence implies that income differences among countries cannot contain unit roots.

Following Bernard and Durlauf (1995), stochastic convergence occurs if the differential log trade system, $y_{t^{\prime}}$ follows a stationary process, where $y_{t}=$ ASEAN4tot $t_{t}$ CJKtot $t_{t^{\prime}}$ where ASEAN4tot $t_{t}$ is the logarithm term of trade of ASEAN4, and CJKtot $_{t}$ is logarithm term of trade of $C J K$, and both series are in the first difference (I(1)). Stochastic convergence is tested by using the conventional augmented Dickey-Fuller (ADF) regression which shows a significance result in proving stationarity for $y_{t}$ (see Table V.8). This indicates long-run convergence between the two trading systems.

\begin{tabular}{|c|c|c|c|}
\hline \multicolumn{4}{|c|}{$\begin{array}{c}\text { Table V.8 } \\
\text { ADF Test for Term of Trade }\end{array}$} \\
\hline \multirow[t]{3}{*}{ ADF Test Statistic } & -3.519465 & $1 \%$ Critical Value* & -3.7204 \\
\hline & & $5 \%$ Critical Value & -2.9850 \\
\hline & & $10 \%$ Critical Value & -2.6318 \\
\hline
\end{tabular}

* Mackinnon critical values for rejection of hypothesis of a unit root.

A major drawback of the standard ADF unit root test procedure is that the power of the test is quite low. To overcome this problem, the paper utilizes cointegration test as suggested by Baharumshah et al. (2007). The following is the Engle Granger Cointegration:

$$
U t=\text { ASEANtot }_{t}-\beta_{o}-\beta_{1} \text { CJKtot }_{t}
$$

\begin{tabular}{|c|c|c|c|}
\hline \multicolumn{4}{|c|}{$\begin{array}{c}\text { Table V.9 } \\
\text { ADF Test for Cointegration Residual }\end{array}$} \\
\hline \multirow[t]{3}{*}{ ADF Test Statistic } & -5.623714 & $1 \%$ Critical Value * & -3.7204 \\
\hline & & $5 \%$ Critical Value & -2.9850 \\
\hline & & $10 \%$ Critical Value & -2.6318 \\
\hline
\end{tabular}

* Mackinnon critical values for rejection of hypothesis of a unit root. 
The residual ( $U_{t}$ ) gives stationary result (see Table V.9) which means that the two regions have long run relationship (convergence). It is worth to say that with the test of convergence, EAR will be there to stay in the long run. The robust finding surely creates optimistic view for EAR. But knowing the future is not enough, we still need to find out the clear path to reach the future. The next section serves to give the answer.

Feng and Genna (2003) argued that homogeneity of domestic institutions is needed to go hand in hand with the regional integration process. Moreover, they pointed out inflation, taxation and government regulation as representing factors for the economic institutions. Another variable that might enhance integration is population as already identified by Tamura (1995). He argued that large population is a catalyst for integration due to economic agglomeration. Scholars like Milner and Kubota (2005) even pointed out democracy as an important factor that could foster regionalism. Their empirical work on the developing countries from 1970-1999 showed that regime change toward democracy was associated with trade liberalization, and regionalization.

Given those works, this paper tries to combine the variables into one complete model that can determine the formation of EAR. The formula as follows:

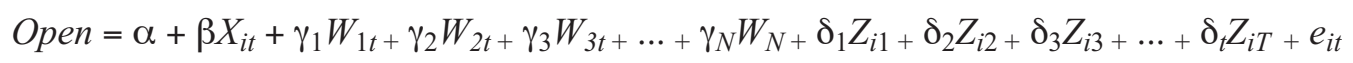

Where:,

Open $_{\text {it }}=$ Regionalism for time $t$ and country $\mathrm{i}$

$\mathrm{X}_{\text {it }}=$ Independent Variables (ASEAN4 + CJK's rail ways, tax, democracy, governance, industry, gross school enrolment rate, inflation and population)

$W_{i t}$ and $Z_{i t}$ are dummy variables which are defined as follows:

Wit $=1$ for country $\mathrm{i}$, where $\mathrm{i}=$ Indonesia, Malaysia, Philippines, Thailand China, Japan, Korea, otherwise 0.

Zit $=1$ for Period $t$ where $t=1998,2000 \ldots, 2007$, , otherwise 0 .

The paper employs fixed effect model to estimate the variables. The followings are the explanations for the variables used:

i) The paper use the proxy of trade openness (net export per GDP) for regionalism. The variable of openness is used to represent regionalism since regionalism creates openness to some sectors of economy. Openness here functions as dependent variable that is determined by some independent variables. 
ii) Railways as goods transported (million ton-km) is used to explain physical infrastructure readiness. Pairing up with this variable is the gross school enrolment rate which serves as the basic for human capital infrastructure. Sound infrastructure (both physical and human) will provide steadiness and assuredness in making investment among members. In other words, good infrastructure will only lead to a sustainable intra trade and investment that serve as the basis of EAR.

iii) To measure democracy, the indices produced by Freedom House (2000) that is the index of democracy called POLITY. Democratization is expected to open up new avenues of support for freer trade vis-à-vis regionalism.

iv) Moving to the next variable is the taxation policy, the higher the rate the more it will diminish the prospects of EAR

v) Other variable that also matters is governance which is measured by the six governance indicators estimated by Kaufmann (2003). These indices describe various aspects of the governance structures of a broad cross section of countries, including measures of Voice and Accountability, Political stability, Government Effectiveness, Regulatory Quality, Rule of Law, and Control of Corruption. In general, the Governance index provides explanatory power to explain the capability and quality of governance from each member country. The better indicator a country has the more it has the chance to capitalize regionalism.

vi) Macroeconomic variable which is represented by inflation creates ambiguous expectation. High inflation might deter the formation of EAR since the very beginning but some scholars prove the other way aroun4. One of argument that supporting the latter proposition is given by Cohen (1997) who argued that the inflationary policy (high inflation) resulting from the government action will tend to raise the obstacle to private investors which in turn demand for greater integration. The loss of discretion in the fiscal and monetary policy will then reduced the risk of uncertainty. vii) Large market together with the ongoing industrialization process sums up the last aspects of EAR formation. The sheer size of the East Asian population creates not only the potential demand for the goods traded in the region but also the supply of labor force and the low absolute level of wages. In other words, Lewis's unlimited supply of labor will persist longer in East Asia. The process will lead to an upward trend towards industrialization (value added as percentage from GDP) in the region. The trend is very important since homogeneity in industrialization among countries in the region will smooth the progress of EAR.

The results shows us that Economic and political factors such as Infrastructure (railways and gross education), governance, taxation policy, industrialization and Democracy have significant effect towards Regionalism (Openness) in East Asia while Inflation gives insignificant role. 


\begin{tabular}{l|r|r}
\multicolumn{3}{c}{ Table V.10. } \\
Factors Affecting Openness \\
\hline \multicolumn{3}{c}{ Dependent Variable : OPENNES } \\
\hline Independent Variable & Coefficient & t-Statistic \\
\hline LOG (RAILWAYS) & 0.115860 & $2.059379 * *$ \\
TAX & -0.029831 & $-3.530943 * * *$ \\
DEMOCRACY & -0.004282 & $-2.051852 * *$ \\
GOVERNANCE & 0.257508 & $3.860438 * * *$ \\
INDUSTRY & 0.049930 & $4.861010 * * *$ \\
LOG (POPULATION) & 0.863634 & $2.154852 * *$ \\
GROSS EDUCATION & 0.011445 & $2.217493 * *$ \\
INFLATION & -0.001545 & -0.441719 \\
\hline R-squared & 0.99251 & \\
Adjusted R-squared & 0.98975 & \\
\hline
\end{tabular}

Note: Statistical significance is indicated by $*(10 \%), * *(5 \%)$, and $* * *(1 \%)$

The signs of coefficient for railways, gross education, governance, and industrialization are positive which mean the bigger the variable the more they create Openness. The negative sign of the coefficient for tax describes the opposite relation between corporate tax rate and the future prospect of EAR, the higher the rate the more it will the deteriorate the EAR. The negative sign of democracy is against expectation but it is still rational since democracy is still finding its form in East Asia. We have to define what democracy really means in order to make it works. The insignificant role of inflation for EAR is expected due to the ambiguity given.

\section{CONCLUSION}

We have made an interim conclusion that export leads the overall growth in North East Asia. However, it is important to note that Japan's phase of adjustment towards long run equilibrium is quite slow compared to the likes of Korea and China. This only yields as a stumbling block in forming regionalism in East Asia. The hard task is about making these countries move together in the same phase, which is why regionalism has to take place.

Since regionalism is an abstract term, the use of RPL index is essential. RPL index is a proxy of outward orientation of a country or in other words it is a representation of regionalism. Regionalism in this case goes hand in hand with openness in which it creates trade arrangements that liberalize some sectors in the economy. The ECM simulation gives a clear picture of the current form of openness which is below the equilibrium. It suggests that the trend towards 
regionalism is still far behin4. It somewhat confirms the ineffectiveness of current triangular trade in North East Asia. It is expected that regionalism can eliminates such bias in trade.

Moreover, since North East Asian countries has a big scale of economy, its economic development will substantially affect the neighboring countries in East Asia specifically ASEAN4. It is demonstrated by the large share of China-Japan-Korea growth that affects ASEAN4's GDP.

In the short run, there is a rivalry competition between China and ASEAN. However, in the long run regionalism is expected to accommodate export growth for East Asia as whole. In a sense of creating integration in East Asia, there is a need to set up more formal institutional mechanisms for trade. It is rational for such mutually dependent countries in the region to institutionalize de facto integration through the establishment of regional arrangements (Kawai, 2005). The growing significance of China, Japan and Korea market for ASEAN4 will then serve as the basis for a single East Asian Wide FTA. The next task is to shape the future of EAR, but then will the future exist? Using the test of convergence, it is found that EAR will be there to stay. The robust finding surely creates optimistic view for EAR. But knowing the future is not enough, we still need to find out the clear path to reach the future. What are the paths then? From a static panel data simulation it is found that sound physical infrastructure, good governance, inflation, competitive taxation policy, sizeable market and the trend towards industrialization are the main factors that serve as building blocks for EAR.

To wrap up, EAR will enable the region to cope with the future challenges of globalization and remain internationally competitive. An integrated East Asia would lead to the advancement in economies of scale, fuller development of production networks. Moreover, Chia (2007) stated that EAR could help the less developed East Asian economies which would otherwise become marginalized as they lack the attraction of sizeable market and lack negotiating resources. 


\section{REFERENCES}

Akamatsu, Kaname. (1935) 'Wagakuni yomo kogyohin no susei [Trend of Japanese Trade in Woolen Goods], Shogyo Keizai Ronso', Journal of Nagoya Higher Commercial School, Vol. 13, pp. 129-212.

Angrist, J. D, \& Imbens, G. W. (1995) 'Two-stage least squares estimation of average causal effects in models with variable treatment intensity', Journal of the American Statistical Association, Vol. 90, pp..431-442.

Arellano, M. (1995) 'On the testing of correlated effects with panel data', Journal of Econometrics, Vol. 59, pp. 87-97.

Bernard, A. 2., \& Durlauf, S. N. (1995) 'Convergence in international output'. Journal of Applied Econometrics, Vol. 10, pp. 97-108.

Chan, Sarah and Chun-Chien Kuo. (2005) 'Trilateral Trade Relations among China, Japan and South Korea:Challenges and Prospects of Regional Economic Integration', Journal of East Asia, Vol. 22, pp. 33-50.

Chia, Siow Yue. (2006) 'ASEAN-China Economic Competition and Free Trade Area', Asian Economic Papers, Vol. 4, pp. 109-147 . (2007) ,Challenges and Configurations of a Region-wide FTA in East Asia', FONDAD Conference.

Cohen, Benjamin J (1997) 'The Political Economy of Currency Regions', in Helen Milner and Edward Mansfield (eds) The Political Economy of Regionalism, New York: Columbia University Press.

Dollar, Davi4. (1992) 'Outward Oriented Developing Economies Really Do Grow More Rapidly: Evidence From 95 LDCs, 1976-85', Journal of Economic Development and Cultural Change, Vol. 4, pp. 523-544.

Doraisami, Anita. (1996) Export Growth and Economic Growth: A Reexamination of Some Time-Series Evidence of the Malaysian Experience ', Journal of Developing Areas, Vol. 30, pp. 223-230.

Ekanayake, E.M. (1999) 'Export and Economic Growth in Asian Developing Countries: Cointegration and Error-Correction Models', Journal of Economic Development, Vol. 24, pp. 43-56. 
Engle, R.F. and 3.W.J. Granger. (1987) 'Cointegration and Error Correction: Representation, Estimation and Testing', Econometrica, Vol. 55, pp. 251-76.

Feng, Yi and Gaspare M. Genna. (2003) Regional integration and domestic institutional homogeneity: a comparative analysis of regional integration in the Americas, Pacific Asia and Western Europe', Review of International Political Economy, Vol. 10, pp. 223-230.

Frankel, Jeffrey A. and David Romer. (1999) 'Does Trade Cause Growth?, The American Economic Review, Vol. 89, pp. 379-399.

Harrison, Ann. (1996) 'Openness and Growth: A Time Series, Cross Country Analysis for Developing Countries', Journal of Development Economics, Vol.48, pp. 419-447.

Harvie, Charles and Hyun Hoon Lee. (2002) 'New Regionalism in East Asia: How Does It Relate to the East Asian Economic Development Model', University of Wollongong Department of Economics, Working Paper Series.

Holst, David Roland and John Weiss. (2004) 'ASEAN and China: Export Rival or Partners in Regional Growth?', Blackwell Publishing Lt4.

Kaufmann, Daniel, Aart Kraay and Massimo Mastruzzi. (2003) 'Governance Matters III: Governance Indicators for 1996-2002', World Bank Policy Research Department Working Paper.

Kawai, Masahiro, (2005) East Asian Economic Regionalism: Progress and Challenges, Asian Economics, Vol. 16, pp. 29-55.

Kawai, Masahiro and Ganeshan Wignaraja. (2007) 'Regionalism as an Engine of Multilateralism:

A Case for a Single East Asian FTA', ADB Working Paper series on Regional Economic Integration no.14.

Love, Jim and Ramesh Chandra. (2004) 'An Index of Openness and its Relationship with Growth in India', The Journal of Developing Areas, Vol. 38, pp. 37-54

Milner Helen V and Keiko Kubota. (2005) 'Why the Move to Free Trade? Democracy and Trade Policy in the Developing Countries,' International Organization, Vol. 59, pp. 107-143.

Nachrowi,Djalal. (2007) 'Ekonometrika Untuk Analisa Ekonomi dan Keuangan [Econometrics for Economic and financial analysis]', Faculty of Economics University of Indonesia.

Oxley, L., \& Greasley, 4. (1995) 'A time-series perspective on convergence: Australia, UK and USA since 1870'. The Economic Record, Vol. 71, pp. 259-270.

Summers, R. and A. Heston. (1988) 'A New Set of International Comparisons of Real Product and Price Levels: Estimates for 130 Countries, 1950-1985', Review of Income and Wealth, Vol. 34, pp. 1-25.

Stubbs, Richar4. (2002) 'ASEAN PlusThree: emerging East Asian Regionalism?', Asian Survey, Vol. 42, pp. 440-455. 
Tamura, Robert. (1995) 'Regional economies and market integration', Journal of Economic Dynamics and Control, Vol. 20, pp. 825-845.

Urata, Shujiro and Kozo Kiyota. (2003) 'The Impacts of an East Asia Free Trade Agreement on Foreign Trade in East Asia', NBER Working Paper Series 10173, National Bureau of Economic Research, Cambridge.

Yoshida, Tadahiro. (2004) 'East Asian Regionalism and Japan', IDE APEC STUDY CENTERWorking Paper Series.

Watanabe, Yorizumi. (2008) 'Economic Partnership Agreement (EPA) of Japan and Economic Integration in Northeast Asia', Academic presentation, Graduate School of Media and Governance, Keio University.

Xing, LI. (2007) 'East Asian Regional Integration: From Japan-led "Flying-geese" to Chinacentred "Bamboo Capitalism"', CCIS Research Series Working Paper No.3. 